\title{
The Different Views on Life between Daoism and Destructive Cult
}

\author{
Weijia Zeng ${ }^{1}$ \\ ${ }^{1}$ Southwest University of Political Science and Law, Chongqing, China \\ Correspondence: Weijia Zeng, Southwest University of Political Science and Law, Chongqing 401120, China. \\ E-mail: zengwja@gmail.com
}

Received: June 8, 2012 Accepted: July 3, 2012 Online Published: October 26, 2012

doi:10.5539/ass.v8n13p264 URL: http://dx.doi.org/10.5539/ass.v8n13p264

This thesis is financially aided by Chongqing Municipal Education Commission Program. No.: 12SKC01

\begin{abstract}
The meaning of life in the view of Daoism and destructive cult is absolutely different. Daoism believes that the life is invested by the dao, and the dao has the virtue to cherish life. Such notions are a truly manifestation of Daoist idea about cherishing life, and abominating death. However, destructive cults apotheosize their chief leaders and regard them as the supreme authority. The chief leaders either say they are God or that they alone can interpret the scriptures the way God intended. The extreme of the destructive cults usually emphasize eschatology and use mind control techniques to overcome the members' critical thinking abilities and free will, so as to lead many suicide and killing.
\end{abstract}

Keywords: Daoism, destructive cult, life, Dao, mind control

What is life? How should human beings treat life? The long history of human civilization is featured by meditation on life, thus gives birth to various philosophies of life, some pessimistic, some optimistic, some aggressive, and some obedient. The indigenous traditional Chinese religion Daoism contributes one to us, which gives uo a positive antitude twards life. On the contuary, Destructive cult disregard life and harm life. In this article, I explore the inner structure of Daoist philosophy of life from the following aspects and focus on their relations to the dao, and analyse the reason why the destructive cult disregard life.

\section{Daoist Philosophy of Life}

Dao is a valuable contribution to humanity through philosophical Daoism and religious Daoism. Both philosophical and religious Daoism take the dao, which begets and dominates myriad things and manifests itself in them, as their most fundamental concept and highest category. Angus C. Graham has pointed out that dao can be seen as the basis of all existing things, the law governing their development and change, and the ultimate god of Daoism. In religious terms, Livia Kohn argues that the dao is a mystical power of universal oneness, a fundamental ontological entity or absolute truth. The whole doctrine of philosophical Daoism and religious Daoism is attributed to the dao, such as Daoist ontology, dao-nature theory and Daoist mind-nature theory, as undoubtedly illuminated by the dao. The Daoist philosophy of life, as the most distinctive and expressive part of the Daoist philosophy, takes spiritual and material immortality as its cardinal tenet and strives to achieve an ideal level of surpassing human life limits through various ways and leads the faithful to an eternal life. In Daoist philosophy of life, the dao plays the role of core concept. All other pertinent notions, such as the belief in immortality, definition of life, and all kinds of ways to surpass life limits, are all built upon this core concept.

\subsection{Unity of Human and the Dao-concept of the Immortal (Xian)}

The highest ideal of the religious Daoism is to acquire immortality, which highlights the profound understanding of the relationship between the dao of ultimate universe and the life of human beings, and further demonstrates that the meaning and value of humans lies in the combination of these two things.

Immortality is an ideal model of preserving human's life and this notion is constructed by the instincts of human beings. Keeping the body healthy and forever preserving its harmonious functions demonstrate fulfillment of human nature, suppress the cause of decrepitude and death, and highlight the absoluteness and perpetuity of life's meaning. To achieve this goal, one must cultivate the dao both inside and outside one's existence and practice oneself both spiritually and physically. Only when one can nourish and prolong one's life and achieve a 
state of perpetuation, can the finiteness of an individual be surpassed and freedom achieved. Based on the ontological theory that the dao is the origin of myriad things, religious Daoism upgrades the natural human desire for immortality to a higher level of religious philosophy, which in turn forms the Daoist philosophy of life. Daoism takes the immortality belief as its main notion. The immortals (xian) are ordinary persons who reach an ideal state of existence after a certain practice, surpass their life limits to a level of eternity, and perhaps even possess supernormal power, and thus acquire both longevity and immortality.

Although the immortals can ascend to heaven and descend to earth, and live as long as heaven and earth, they are still human beings, worldly people with the dao, and simply people who have surpassed their life limits. It can be said that the immortality theory is a bold idea centering on the concept of dao which puts out an aim for humans to surpass their life limits from the perspective of the philosophy of life and provides an ideal model for human beings to pursue from the perspective of religion.

\subsection{Goodness (Shan) and the Dao}

"Reward for Good and Retribution for Evil" is one of the important parts of religious ethics and morality, which restricts the mind and dictates the behaviors of the disciples, and limits them within the framework of religious teaching. Buddhism, for example, postulates that the phenomena and situation of an individual sentiment being hold their originators responsible and accountable. In other words, whenever one acts, speaks, or even thinks, he does something which must produce results. This result is the retribution of Karma which takes place through a sequence of countless existences and may involve a movement through a vast variety of forms of life. Similarly, religious Daoism believes in retribution and therefore advocates doing good deeds. It does not regard good deeds merely as alms to others but holds that the results of good deeds benefit not only others but also oneself, for the virtue (de) is an attribute of the dao that resides in the heaven and pervades in myriad things as such. That's the reason why the myriad creatures all revere the dao and honor the virtue and why the man with perfect virtue cannot be harmed by anything. Doing good deeds, of course, is a manifestation of the virtue, and contains the perfection of one's own personality. While beneficial for the others, good deeds create conditions for the perfection of one's own cultivation. Daoism considers the morality, ethics and norms as active ways to regulate the secular society while supplementing the ways of cultivating the dao. It is this value concern that initiates the special path of life practice. Daoist philosophy of life links goodness and evil with life and death, and judges the possibility of surpassing life limits and the degree of attaining ultimate solicitude according to the standard of our moral levels. However, it explains concerning concepts such as goodness and evil around the dao as well.

In the course of development, goodness evolved into another important condition for longevity and immortality. Just like Gehong claims that one, who just does occult practice and takes medicines but does not accumulate enough good deeds, cannot achieve immortality. Those who aspire to immortality must accumulate enough good deeds, be happy in other's happiness, commiserate with other's suffering, relieve the needy, save the poor, and show benevolence to animals and insects. These are the mandates of becoming immortals, and abiding by the precepts of morality is real virtue, and will be blessed by the Heaven.

In Daoist opinion, doing good deeds shows obedience to the decree of Heaven. Moreover, Daoism highlights the concept of goodness and equates it with the dao. It can be said that goodness is the dao, and the dao is goodness. Equating the goodness with the dao promotes the ontological premise for religious Daoism to advocate the moral and the ethics, and puts goodness on a base of "absoluteness." The definition of "goodness" is no more a vacillation for the reason of being testified by the results of material gain or the experiential aim, but has gained a fixed meaning and criteria for it connected with the root of life: dao. In addition, when it evangelizes people with its religious ethics, a personified great dao or heavenly dao always admonishes the people "not to do evil and worship the good." In this way, Daoism elevated ethics to a very high status, making it a necessary condition for immortality.

\section{Destructive Cult's View on Life}

Destructive cult usually establishes its organization by fraudulent use of religion, apotheosize its chief leader, and control its members by using grotesque and strict measures. It creates a definite worship system, claims having a "super-natural" hierarch, torture followers' rational thoughts, and performs mental control. This kind of organization always spreads superstitious fallacies doctrines to confuse and deceive others, and thus forms a danger to society. After the Second World War, especially since the 1970s, along with the prevalence of new religious movements, the activities of destructive cult became increasingly rampant and made a series of world-shaking murder cases. In recent years, organizations of destructive cult are developing rapidly all over the world, not only in the developed areas, like Europe and America, but also in the developing countries, like China. Being a social phenomenon, destructive cult appeared with its historical necessity and complex reasons. It is 
partly from religion but go to extremes, so it is qualitative changes from religion and hold thorough distinction from religion, especially at the viewpoints towards life.

\subsection{Messianic Leader}

The destructive cult is authoritarian in its power structure. The leader is regarded as the supreme authority. In the group, the members basically give up much of their critical thinking, and defer to the leader. What leader says is what they think, and they allow him to make value judgments for them. The leader may delegate certain power to a few subordinates for the purpose of seeing that members adhere to the leader's wishes and roles.

The cult's leader is self-appointed, messianic person who claims to have a special mission in life. Therefore, he centers the veneration of members upon himself. Daoism keep the veneration of adherents focused on Dao, abstract principles, and group purposes. Cult leader, in contrast, keep the focus of love, devotion, and allegiance on him. He tends to be totalitarian in the control of the behavior of his members, including what members wear, eat, when and where they work, sleep, and bathe-as well as what to believe, think, and say.

Because the destructive cult leader is actually ordinary people, but he wants to act a messianic role, he tends to have a double set of ethics. Members are urged to be open and honest within the group, and confess all to the leader. On the other hand, they are encouraged to deceive and manipulate outsiders or nonmembers. Established religions, such as Daoism, teach members to be honest and truthful to all, and to abide by one set of ethics.

In general, destructive cult's leader controls their members by way of maintaining intense allegiance through the arguments of their ideology, and through social and psychological pressures and practices that, intentionally or not, amount to conditioning techniques that constrict attention, limit personal relationships, and devalue reasoning.

\subsection{Mind Control}

Mind control or brainwashing in academia is commonly referred to as coercive persuasion, coercive psychological systems or coercive influence. Mind control has coercive psychological influence which can overcome the individual's critical thinking abilities and free will - apart from any appeal to informed judgment. The cult's members gradually lose their ability to make independent decisions and exercise informed consent. Their critical thinking, defenses, cognitive processes, values, ideas, attitudes, conduct and ability to reason are undermined by a technological process rather than by meaningful free choice, rationality, or the inherent merit or value of the ideas or propositions being presented.

In order to attain this aim, the cult's leader tends to be charismatic, determined, and domineering. Besides, most destructive cults rely on isolation; the leader persuades followers to drop their families, jobs, careers, and friends to follow him. That means that the leader begins to monopolize the members' time, controls their environment, in such a way that he cuts them off from their families, from their old friends, from their co-worker. Because what the group wants is to control everything they see, everything they experience, and in that way control their mind. In this way, the cult's leader can cause people to become so preoccupied with the group that they neglect other things.

At first, they will increase suggestibility and "soften up" the individual through specific hypnotic or other suggestibility-increasing techniques such as: extended audio, visual, verbal, or tactile fixation drills, excessive exact repetition of routine activities, sleep restriction or nutritional restriction. After that, they will establish control over the person's social environment, time and sources of social support by a system of often-excessive rewards and punishments. Social isolation is promoted. Followers are persuaded to drop their families, jobs, careers, and friends to follow the cult's leader. That means that the leader begins to monopolize the members' time, controls their environment, in such a way that he cuts them off from their families, from their old friends, from their co-worker.

The next step is to prohibit disconfirming information and non supporting opinions in group communication. The members will be instructed many rules and permissible topics to discuss with outsiders. Their communications are highly controlled, and an "in-group" language is usually constructed at this time.

These tactics of psychological force are applied to such a severe degree that the member's capacity to make informed or free choices becomes inhibited. The members become unable to make the normal, wise or balanced decisions which they most likely or normally would have made, had they not been unknowingly manipulated by these coordinated technical processes. The cumulative effect of these processes can be an even more effective form of undue influence than pain, torture, drugs or the use of physical force and physical and legal threats. 


\subsection{Disrespects Human Life}

Thoroughly imbued with the leaders' "doctrines," the members will lose their judgment and the ability to reason by and by, and some even suffer from mental disorders. Under the guidance of the doctrine and absolute one-way information receiving, the members are asked to read the leader's books, listen to his tapes and watch his videos whenever they have time so as to "advance" in the studies. In fact, some disciples are totally sealed off and lose interests in doing or thinking about other things. As time goes by, the members get accustomed to hypnotic practices and their minds are full of heresies. Eventually they are completely brain-washed to lose judgment and the ability to reason. Furthermore, under intensified inculcation and strong temptation, many members have difficulty in controlling themselves: some suffer from illusion or other mental disorders; a few of them are totally out of mind and kill themselves.

As far as human being is concerned, life is the most precious existence in the world. Then, why do the destructive cults' obsessed practitioners disrespect human life? Why do some of them even commit suicide or cruelly kill others?

From the cult's disciple's perspective, the flesh body is just "a set of skin," the earlier you get rid of it, the sooner you feel relieved. In addition, when a person dies, only the human shell on the surface falls away from this dimension. His real body will not die. If a disciple "gets rid of his human shell due to persecution," he will even be able to "gain Consummation." Furthermore, when someone returns to his paradise, he does not need to take his flesh body with him.

In order to turn his followers into diehards, the leader calls on his disciples to eliminate all worldly attachments (including the ones to human body), encouraging them to "lay down life and death to reach Consummation." The leader of The Peoples Temple James Warren Jones developed a belief called "Translation" in which he and his followers would all die together, and would move to another planet for a life of bliss. November 18, 1978 they reach a consensus to commit group suicide. Most appear to have committed suicide by drinking a grape drink laced with poison. In all, 914 died: 638 adults and 276 children.

Fascinated with Paradise and Consummation vividly depicted by the leader, the disciples discard kinship affections and disregard humanity; some of them even commit suicide by setting fire to themselves or jumping off buildings, hoping to reach Consummation by "Laying down worldly attachments." On January 23, 2001, seven Falun Gong practitioners made the shocking self-immolation incident on Tianan Men Square.

The destructive cult disciples regard people who interfere in their cultivation as "the demons." In order to "cultivate into a high level," and to "eliminate the evil and eradicate the demons," the cult disciples have cruelly killed many innocent people. In 1984, a group of followers of Osho carried out what has come to be known as the first bioterrorism attack in the United States. Over seven hundred and fifty individuals became ill from salmonella poisoning, after the group had deliberately contaminated the salad bars of ten restaurants. Another example is the leader Asahara calling for the group to fight in a final world revolution against the enemies, including the US. The group established a number of chemical factories and stockpiled various chemicals, as preparation for this Armageddon. On March 20, 1995, Asahara ordered the spreading of a nerve gas, Sarin, in a Tokyo subway station. The gas killed 12 passengers and injured over 5000 .

\section{Epilogue}

In general, Daoism believe that the life is invested by the dao, and the dao has the virtue to cherish life. Such notions are a truly manifestation of Daoist idea about cherishing life, and abominating death. Mottos such as "death is the greatest disaster and life is the best fortune," and "A dead prince is not worth a live rat" can be often found in Daoist scriptures. Daoist Adepts take immortality as their supreme purpose and hold that thoroughly remolding themselves and getting apotheosized are the symbols of success in their life time. To achieve this goal, they must cultivate themselves by internal practice which involves refining the interior elixirs and concentrated contemplation, and external practice which involves doing good deeds and acquiring more merits and virtues. From the analysis of this paper, we can see the theories of all these practices are based on the core concept dao. Daoist philosophy of life not only teaches us the way to keep the body immortal but also reveals the meaning of life laying in making friends with the dao and following the dao. Revealing that the truth of life is based on naturalness and freedom, Daoist philosophy of life is not a negative philosophy of life which just aims to preserve human's life, but rather a positive philosophy of life which goes beyond the natural life from a narrow field of vision, so as to open a wider view for us to deal with our lives. It tells us that we should not only pay attention to the importance of living a life, but also to the importance of living a significant life.

The destructive cults have no their own system of doctrine, so they usually plagiarize traditional religious 
teachings, and thus confuse the public and the ordinary believers. Although the doctrines of destructive cults are similar with the general religious teachings, the difference between them is fundamental. The main character of destructive cults' teachings is the extreme uses of normal religious teachings. When we parse the People's Temple, God's children, David, the tribe of the Solar Temple, Rajneesh retreat, Aum Shinrikyo and recognized by the seven men of the heaven's Gate cult, we found that the extreme of these destructive cults focus in two aspects: the absolute supremacy of the leader, and the specific eschatological.

\section{References}

Conway, F., \& Siegelman, J. (1978). Snapping: America's Epidemic of Sudden Personality Change. J. P. Lippencott Company.

Creel, H. G. (1982). What is Taoism? And Other Studies in Chinese Cultural History. University of Chicago Press.

Dawson, L. L. (1998). Cults in Context: Readings in the Study of New Religious Movements. Transaction Publishers.

Ellis, J. K. (2006). Perfected Mind Control - The Unauthorized Black Book of Hypnotic Mind Control. Lulu.

Ford, R. (2002). To Live as Long as Heaven and Earth: A Translation and Study of Gehong's Traditions of Divine Transcendents. University Of California Press.

Goldberg, C., \& Crespo, V. (2004). Seeking the Compassionate Life: The Moral Crisis for Psychotherapy and Society. Greenwood.

Gordon, J. (1981). Destructive Cult Conversion: Theory, Research and Practice. Weston, Massachusetts: American Family Foundation.

Graham, A. C. (1989). Disputers of the Tao: Philosophical Argument in Ancient China. La Salle, Ill.: Open Court.

Gregg, S. (2000). The Complete Idiot's Guide to Spiritual Healing. Alpha Books.

Hall, H. V. (1999). Lethal Violence. CRC Press.

Kaslow, F. W., \& Sussman, M. B. (1982). Cults and the Family. Haworth Press.

Kirkland, R. (2004). Taoism: The Enduring Tradition. Routledge.

Kohn, L. (2001). Daoism and Chinese Culture. Cambridge: Three Pines Press.

Maspero, H. (1981). Taoism and Chinese Religion. The University of Massachusetts Press.

Olsson, M. D., \& Peter, A. (2005). Malignant Pied Pipers of Our Time: A Psychological Study of Destructive Cult Leaders from Rev. Jim Jones to Osama bin Laden. Publish America, Incorporated.

Page, J. (2002). Survivors say China Falun Gong immolation real. Reuters.

Robinet, I. (1997). Taoism: Growth of a Religion, trans. Phyllis Brooks. California: Stanford University Press.

Saliba, J. A. (2003). Understanding New Religious Movements. Rowman Altamira.

Schipper, K. (1993). The Taoist Body. University of California Press.

Welch, H. (1957). The parting of the Way: Lao Tzu and the Taoist Movement. Boston Press.

Zablocki, B. D., \& Robbins, T. (2001). Misunderstanding Cults: Searching for Objectivity in a Controversial Field. University of Toronto Press. 